\title{
Didactic Transposition On The Concept Of Central Angle And Circumferential Angle In Junior High School
}

\author{
Winarji ${ }^{1}$, Turmudi $^{2}$ \\ \{agus.winarji@upi.edu ${ }^{1}$ \} \\ Program Studi Pendidikan Matematika, Sekolah Pascasarjana, Universitas Pendidikan Indonesia, \\ Jl. Dr. Setiabudi No. 229, Bandung 40154, Indonesia ${ }^{1}$ \\ Departemen Pendidikan Matematika, Fakultas Pendidikan Matematika dan IPA, Universitas \\ Pendidikan Indonesia, Jl. Dr. Setiabudi No. 229, Bandung 40154, Indonesia²
}

\begin{abstract}
A study was conducted to analyze the didactic transposition process on the concept of central and circumferential angles in junior high school. This research is a hermeneutic phenomenology research. Geometry textbooks, the 2013 curriculum and junior high school mathematics textbooks are the data sources in this study. Descriptive analysis is used to analyze the didactic transposition process. The results of this study indicate that there is no structural change in the concept of the central angle and the circumferential angle from scholarly mathematics to school mathematics. But there is a change in form (content) in the concept of the central angle and the circumferential angle from scholarly mathematics to school mathematics. In school mathematics, the concepts presented are contextual, concrete and simple. Whereas in scholarly mathematics, the concepts presented are abstract. This change in form adjusts the level of cognitive development of students.
\end{abstract}

Keywords: Didactic transposition, Central angles, Circumferential angles

\section{Introduction}

The concept of didactic transposition refers to the transformation of an object or a body of knowledge from the knowledge generated, selected and designed to be taught, until it is actually taught in certain educational institutions [1]. This concept shows the fact that knowledge taught in schools comes from other institutions, where the knowledge taught is generally from universities or other scholarly institutions [1]. This shows that mathematical knowledge taught in schools has been generated at scholarly institutions and transferred to schools by a series of adaptation processes [2]. The adaptation process in question is the process of changing (transfer) the knowledge from the knowledge generated (Scholarly knowledge)), to the knowledge chosen and designed to be taught (knowledge to be taught), and ultimately to the knowledge that is actually taught in schools (knowledge taught) and student learning (learnt knowledge). Chevallard calls this activity a didactic transposition process [2]. The didactic transposition process can be seen in Figure 1.

The concept of circle is one of the concepts taught in junior high school that has started at the elementary school level. This concept continues to the next level. The concept of this circle has certainly transposed from the concept of the circle contained in scholarly mathematics. 
In this article, we will explain the didactic transposition process on the concept of circles, especially the relationship of the central angle and the circumferential angle. This transposition enables changes in knowledge that can be seen from aspects of structure (sequence) and form (content).

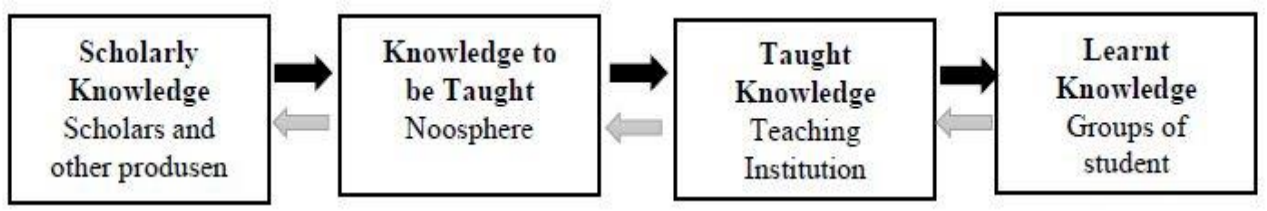

Fig. 1. Diagram of the process of didactic transposition.

\section{Experimental Method}

This research is a qualitative research with hermeneutic phenomenology research. Phenomenology is an approach used to understand hidden meanings and essences related to human experience or phenomena that occur in humans [3]. While hermeneutics, according to Butler is interpreted as an interpretation of meaning [3]. Thus hermeneutic phenomenology is an approach to understand or study the meaning of a phenomenon that occurs and interpret the meaning based on the phenomenon. In this case the phenomenon is a didactic transposition process on the concept of the central angle and the circumferential angle of the circle.

In this article, we will describe how curriculum designers and textbook authors carry out didactic transposition processes. Data sources used to obtain this information are scholarly mathematics textbooks (geometry textbooks), school mathematics textbooks and the 2013 curriculum documents. Data were analyzed using descriptive analysis. This analysis includes a description of the concepts of the central angle and the circumferential angle of the circle in the perspective of scholarly mathematics and school mathematics viewed from the aspect of the structure and form of the content.

\section{Result and Discussion}

\subsection{The concept of circles (center angles and circumferential angles) in the perspective of scholarly mathematics.}

The results of the analysis of the geometry textbook were obtained from the results of the analysis of the book Geometry: The Line and The Circle. The aspects analyzed from the textbook are the structure of the content and the form of the content. The summary of the analysis results can be seen in Table 1 . 
Table 1. Summary of Geometry Text Book Analysis.

\begin{tabular}{|c|c|c|}
\hline Book title & Structure of content & Form of content \\
\hline $\begin{array}{l}\text { Geometry: } \\
\text { The Line and } \\
\text { The Circle } \\
\text { [4] }\end{array}$ & $\begin{array}{l}\text { The content } \\
\text { structure of the } \\
\text { circle concept } \\
\text { consists of the } \\
\text { previous concepts: } \\
\text { 1. Definition of a } \\
\text { circle } \\
\text { 2. Definition of } \\
\text { several terms in a } \\
\text { circle }\end{array}$ & $\begin{array}{l}\text { The definition of circle is conveyed more specifically and in } \\
\text { accordance with the definition of Euclid's circle. A circle is a } \\
\text { plane figure contained by one line such that all the straight } \\
\text { lines falling upon it from one point among those lying within } \\
\text { the figure are equal to one another. } \\
\text { Some terms in a circle (containing elements of a circle) are } \\
\text { conveyed in the form of definitions. Some of these terms } \\
\text { include arc, radius, chord, diameter, arc minor and arc } \\
\text { major, segment of a circle, a sector of a circle, central angle, } \\
\text { circumferential angle, congruent circle, secant line, tangent } \\
\text { line, two tangent circles, and cyclic quadrilateral. } \\
\text { For the terms center angle and circumferential angle are } \\
\text { explained in general terms. } \\
\text { A central angel of a circle is an angle } \angle A C B \text { where A and B lie } \\
\text { on the circle and } C \text { is its center. } \\
\text { Given three distinct points } A \text {, B and D that lie on a circle, } \\
\angle A D B \text { is an angle at the circumference, that intercepts chord }\end{array}$ \\
\hline
\end{tabular}

3. Arc, chord, and angle

In this section, it is related to the relationship between the central angle and the circumferential angle in the form of propositions and evidences derived from the concept of Euclid's circle.

Proposition 20 (star trek theorem)

In a circle, the center angle is double of angle at the circumference

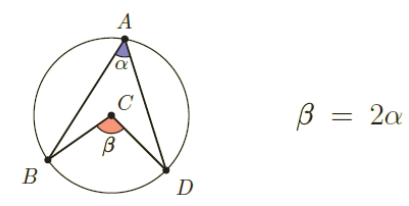

Proposition 21

In a circle the angles in the same segment are equal to one 


Book title $\quad$ Structure of content

Proposition 22

The opposite angles of quadrilaterals in circles are equal to two right angles.

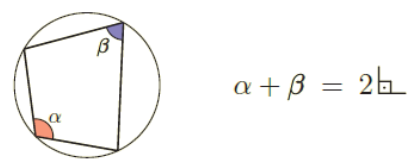

Proposition 26-29 (Circle Equivalence Theorem )

Consider equal circles at $C$ and $C^{\prime}$, respectively, with points $A, B, D$, and $E$ on the circle centered at $C$, and points $A^{\prime}, B^{\prime}$,

$D^{\prime \prime},{ }^{\prime}$, and $E^{\prime}$ on the other. Assume is a minor acr throught

$E$ but not $D$, and $\widehat{A^{\prime} B^{\prime}}$ is a minor arc throught $E^{\prime}$ but $\operatorname{not} D^{\prime}$.

The following are equivalent:
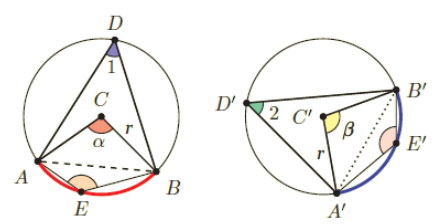

TFAE:

$A B \cong A^{\prime} B^{\prime}$

$\widehat{A B} \cong \widehat{A^{\prime} B}$

$\widehat{A D B} \cong \widehat{A^{\prime} D^{\prime} B^{\prime}}$

$\beta \cong \alpha$

$\angle 1 \cong \angle 2$

Proposition 31 (Thales theorem)

In the circle the angle in the semicircles is right, that in a greater segment less than a right angle, and that in a less segment greater than a right angle

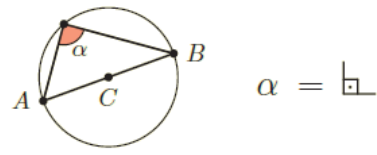

The discussion of the relationship between the central angle and the circumferential angle not only uses one circle but also uses two circles, especially the discussion of the equivalent circle theorem. 


\subsection{The concept of circles (center angles and circumferential angles) in the perspective of school mathematics}

In school mathematics, the concept of a circle is a basic concept that is sustainable and is presented starting at the elementary school level. In this article what will be analyzed is the concept of a circle in junior high schools (SMP) especially the relationship between the central angle and the circumferential angle.

The results of the analysis of school mathematics textbooks were obtained from the results of the analysis of the 8th grade junior high school mathematics textbook consisting of student books and teacher books. The aspects analyzed from the textbook are the structure (sequence) of the material and the content (form) of the material. The textbook analysis process is also based on the structure of the school mathematics curriculum. A summary of the results of the analysis on the curriculum and school mathematics textbooks can be seen in Table 2.

Based on the Amendment to the Minister of Education and Culture Regulation number 37 of 2018 concerning core competencies and basic competencies of lessons in the 2013 curriculum in basic education and secondary education, it is stated that the basic competencies that must be possessed by VIII grade junior high school students on circle material for knowledge aspects are 1) explaining central angle, circumferential angle, arc length, area of circle circle and the relationship; and 2) explain the tangent of external alliance and alliance in two circles and how to paint it. While the basic competencies that must be possessed by VIII grade junior high school students on the aspect of skills are 1) solving problems related to the central angle, the circumferential angle, the length of the arc and the area of the circle's circle and the relationship; and 2) resolving problems relating to the tangent of the external alliance and the fellowship in two circles [7].

Table 2. Summary of Analysis Results of Junior High School Mathematics Textbooks.

\begin{tabular}{|c|c|c|}
\hline Book title & Structure of content & Form of content \\
\hline $\begin{array}{l}\text { School } \\
\text { Mathematics } \\
\text { Textbooks } \\
{[8],[9]}\end{array}$ & $\begin{array}{l}\text { The circle material structure } \\
\text { presented in this book } \\
\text { consists of: } \\
\text { 1. Definition of a circle } \\
\text { 2. Circle elements }\end{array}$ & $\begin{array}{l}\text { In this section, the discussion of the } \\
\text { concept of circles is presented in the form of } \\
\text { examples and non-examples. Some examples } \\
\text { (problems) are presented in contextual form. But } \\
\text { in this section, the definition of a circle is } \\
\text { presented in a general form and not as specific as } \\
\text { Euclid's definition. } \\
\text { The circle is one simple closed curve that divides } \\
\text { the plane into two parts, namely the inside and } \\
\text { the outside of the circle. } \\
\text { The circle elements discussed consist of } \\
\text { arcs, chords, radii, diameters, apothem, a sector } \\
\text { of a circle, and a segment of a circle. These } \\
\text { elements are presented in the form of drawings } \\
\text { and their characteristics are explained. In this } \\
\text { section, it also discusses how to write straight line } \\
\text { symbols (radius, diameter, chord, and apothem), } \\
\text { circular arcs, angles and angular sizes. }\end{array}$ \\
\hline
\end{tabular}




\begin{tabular}{|c|c|c|}
\hline Book title & Structure of content & Form of content \\
\hline & $\begin{array}{l}\text { Relationship Center angle } \\
\quad \text { and } \\
\text { circumferential angle }\end{array}$ & $\begin{array}{l}\text { The relationship between the center angle and the } \\
\text { circumferential angle begins with an explanation } \\
\text { of the terms center angle and the circumferential } \\
\text { angle, accompanied by examples of drawings to } \\
\text { clarify the terms of both. The two terms are } \\
\text { explained in more detail but have the same } \\
\text { meaning as the terms in the geometry textbook } \\
\text { The circumferential angle is the angle where the } \\
\text { angle foot coincides with the chord and the } \\
\text { center point coincides with a point on the circle. } \\
\text { While the central angle is explained with the } \\
\text { characteristics namely } \\
\text { - formed from two ray lines (angle legs) } \\
\text { - Foot angle coincides with the radius of the } \\
\text { circle } \\
\text { - the vertex coincides with the center of the circle } \\
\text { In this section, only the relationship } \\
\text { between the central angle and the circumferential } \\
\text { angle, the relationship of two circumferential } \\
\text { angles facing the same arc and the quadrilaterals } \\
\text { in circles are not presented textually, but are } \\
\text { discovered through student activities/ } \\
\text { experiments. The relationship is only discussed } \\
\text { in one circle. }\end{array}$ \\
\hline
\end{tabular}

\subsection{Didactic transposition to the concept of the central angle and the circumferential angle of the circle}

School mathematics is an evolution of scholarly mathematics produced by mathematicians. This evolutionary process has gone through a series of adaptations in the form of rearranging scholarly mathematics into school mathematics. This adaptation process allows changes in knowledge both from the aspect of structure (sequence) and form (content). This process also occurs in circular concepts that have been selected and rearranged from knowledge contained in scholarly mathematics to knowledge contained in school mathematics.

The results of the analysis of the concept of the circle, especially the relationship between the central angle and the angle around both the scholarly mathematics perspective and school mathematics perspective in terms of two aspects, namely the structure of the material and the form of the material. Judging from the aspect of material structure, the material structure of the concept of a circle (the prerequisite concept, and the concept of the central angle and the circumferential angle) contained in school mathematics is not much different from the concept of the circle contained in scholarly mathematics. Both of them contain the discussion in sequence. Starting from the concept of prerequisites about the definition of points, lines, plane, and angles (in the previous chapter / level); definition of circle; definition of circle elements; and the relationship between the center angle and the circumferential angle. The difference between the two is the discussion of equivalent circle theorem and thalas theorem in scholarly mathematics, whereas school mathematics is not contained. And in school mathematics there is 
discussion of apothem, whereas scholarly mathematics is not contained. Judging from the aspect of the form (content) of the material, in general the concept of a circle (the prerequisite concept, and the concept of the central angle and the circumferential angle) contained in school mathematics in accordance with the concept of the circle contained in scholarly mathematics. However, the discussion in school mathematics is contextual, concrete and simple. This form change, of course, adapted to students' cognitive development.

Some form changes that occur from scholarly mathematics to school mathematics include examples of problems discussed in contextual school mathematics, the term circle elements as a prerequisite concept in school mathematics is explained through characteristic and figures, it is intended to make it clearer the definition of these elements is compared to the explanation of the circle elements in scholarly mathematics which are only in the form of definitions and some use figures. Likewise with the concept of central angle and circumferential angle, both terms are explained with writing differences but have the same purpose. In school mathematics the terms center angle and the circumferential angle are explained in detail and accompanied by figures to clarify the term whereas in scholarly mathematics the terms center angle and the circumferential angle, explained is general.

In discussing the relationship between the central angle and the circumferential angle, scholarly mathematics has a wider scope than school mathematics. In scholarly mathematics the discussion of the relationship between the central angle and the circumferential angle, there is the use of two congruent circles (circle equivalence theorem) whereas in school mathematics only uses one circle. This is one of the recommendations to be conveyed in school mathematics learning.

Both scholarly mathematics and school mathematics, both use proof to check the truth of the concept of the relationship of the central angle and the circumferential angle. The concept which states that the center angle is twice the circumference angle is found through proof. In scholarly mathematics, proofs are abstract, but in school mathematics, the proof is carried out concretely and simply through experimental and measuring activities. This difference is adjusted for students' cognitive development.

\section{Conclusion}

Based on the results and discussion, it can be concluded that there is no change in the structure (sequence) of the concept of the circle (the concept of prerequisites and the concept of the central angle and the circumferential angle) from scholarly mathematics to school mathematics. But there is a change in form (content) from scholarly mathematics to school mathematics. In school mathematics, the concepts presented are contextual, concrete and simple. This is different in scholarly mathematics, where the concepts presented are abstract.

\section{References}

[1] Chevallard, Y.: Didactic Transposition in Mathematics Education. In Encyclopedia of Mathematics Education. (2013)

[2] Bergsten, C., Jabionka, E., \& Klisinski.: A Remark on Didactic Transposition Theory. In: Mathematics and mathematics education: Cultural and social dimensions: Proceedings of MADIF7 (The Seventh Mathematics Education Research Seminar). Stockholm. (2010) 
[3] Suryadi, D.: Landasan Filosofis Penelitian Desain Didaktis (DDR). Makalah bahan diskusi di lingkungan Departemen Pendidikan Matematika FPMIPA UPI. (2018)

[4] Carroll, M. T. \& Rykken, E.: Geometry : The Lien and The Circle. USA: MAA Press. (2018)

[5] Menteri Pendidikan dan Kebudayaan.: Peraturan Menteri Pendidikan dan Kebudayaan

Republik Indonesia Nomor 37 Tahun 2018 (salinan). Diakses dari https://drive.google.com/file/d/1RN8ooBcqwm-3qym-iBub91pK8-ShMbR5/view pada tanggal 1 Agustus 2019 pukul 11.00 WIB. (2018)

[6] As'ari, A. R., dkk.: Matematika SMP/MTs Kelas VIII Semester 2. Jakarta: Pusat Kurikulum dan Perbukuan, Balitbang, Kemendikbud. (2017)

[7] Chevallard, Y.: On Didactic Transposition Theory:Some Introductory Notes. In Proceedings of International Symposium on Selected Domains of Research and Development in Mathematics Education (pp. 51-62). (1989)

[8] Hamilton, R. \& Ghatala, E.: Learning and Instruction. New York: McGraw-Hill. Inc. (1994) 